\title{
ARTICLES
}

\section{On the role of the shape and size of foraging area, and colony size, in selecting critical areas for Cape Griffon Gyps coprotheres conservation action.}

\section{André Boshoff* and Johan Minnie}

Centre for African Conservation Ecology, Nelson Mandela Metropolitan University Port Elizabeth, South Africa

*Corresponding author: andre.boshoff@nmmu.ac.za

\section{Summary}

The Cape Griffon (vulture) Gyps coprotheres, which is endemic to southern Africa, has, despite some conservation action, undergone a marked decrease in range and numbers in the Eastern Cape Province of South Africa. Further such action is now urgently required to halt, and even reverse, this decline. For any strategic conservation plan for this species to succeed, it is necessary to identify those sites or areas where 'on-theground' conservation action must be focused. This exercise should take into account, inter alia, key biological and ecological parameters for the species in question. Noting that the breeding segment of a population is critical for its survival into the future, this article discusses the role of the shape and size of the mean daily foraging area for griffons at active breeding colonies as a means of identifying areas where conservation action should be focused. It transpires that a circular range, with a radius of $40 \mathrm{~km}$ (centred on the active breeding colony) realistically identifies these key foraging areas in the grassland-dominated Eastern Cape. The article also makes a case for the largest (according to number of active breeding pairs) active colonies being a higher priority for conservation action than the smaller ones, and, consequently, the active colonies in the Eastern Cape are ranked from largest to smallest.

\section{Introduction}

The Cape Griffon (vulture) Gyps coprotheres, which is endemic to southern Africa, has, despite some conservation action, undergone an overall decrease in range and numbers, resulting in over $90 \%$ of the current population now being confined to South Africa and Lesotho (Mundy et al. 1992; Piper 1994; Mundy et al. 1997; Piper 2005). For example, the 
species was, historically, common and widespread in the 168000 sq. km Eastern Cape Province (hereafter "Eastern Cape"), one of South Africa's nine provinces, prior to the 20th century (Boshoff $\&$ Vernon 1980), but there is good evidence of a decrease in its range and population size in this region (Boshoff \& Vernon 1980; Piper 1994; Vernon \& Boshoff 1997; Boshoff et al. 2009). Consequently, it has now been accorded 'Vulnerable' status in the South African Red Data Book: Birds (Anderson 2000) and 'Vulnerable' status globally (IUCN 2009).

Despite its overall decline, and resulting fragmented population, the Cape Griffon still occupies a vast area (Mundy et al. 1997), which makes the planning, resourcing, co-ordination and effective implementation and monitoring of conservation measures problematic. Given this situation, a spatial priority assessment that identifies specific areas within the species' current global range that are most in need of focused and appropriate on-theground conservation actions must form an integral part of a strategic conservation plan for the species.

That the breeding segment of a population deserves priority conservation treatment reflects a fundamental and widely accepted biological and conservation principle, namely that the persistence of a threatened species into the future relies on the protection of its breeding sites or areas and, by inference, its breeding population. This has been noted for avian species by, inter alia, Newton (1979) and Bell \& Merton (2002). It is known that, given the long breeding season, breeding Cape Griffons are tied to their breeding colonies for most of the year and that during this period their daily foraging movements are more spatially restricted than during the non-breeding season (Mundy 1982, Mundy et al. 1992, Piper 1994, 2005). These statements support the contention that to protect the Cape Griffon, conservation action within the daily foraging range of adult birds at breeding colonies is of cardinal importance. This article contributes discussion and information on this topic.

\section{Approach and Methods}

Shape and size of daily foraging area In estimating the daily foraging range of Cape Griffons at breeding colonies in the Eastern Cape, it was considered appropriate to use a circular area to represent this parameter, this for two reasons. First, on the basis of the underpinning theory (Orians \& Pearson 1979), the species qualifies as a 'central place forager'. This means that the griffons are tied to a particular colony and they forage within a certain area around that central colony each day, normally returning to it before nightfall. The application of central place foraging theory has been successfully used to identify and study important foraging habitats for Old World vultures (e.g. Carrete \& Donazar 2005, Deygout et al. 2009). Second, the Eastern Cape 
is dominated by grassland ( $40 \%$ of total area), karoo (19\%) and savanna (11\%) vegetation types, which contain almost all the active griffon colonies, and their general structural homogeneity (Mucina \& Rutherford 2006), and the lack of major physical barriers allow for the depiction of generally circular foraging areas.

Information from various studies was combined to enable an estimation of the shape and size of colony-based Cape Griffon foraging areas in the Eastern Cape. The food requirements of Cape Griffons at the Potberg colony, within the De Hoop Nature Reserve near Bredasdorp in the Western Cape, were met within an area around the colony with a radius of $35 \mathrm{~km}$ (Jarvis et al. 1974). The birds from this colony forage mainly in an open patchwork of wheat fields and pastures, with some remnant patches of coastal renosterveld (relatively low growing). The results of a postal survey of farmers provided similar findings; griffons from the Potberg colony had a roughly circular foraging range (apart from an area comprising the sea) with a maximum radius of $40 \mathrm{~km}$ from the colony (Robertson \& Boshoff 1986). A study in the grassland-clad Drakensberg, recorded marked birds at carcasses 34, 38 and $39 \mathrm{~km}$ from griffon sites (Brown \& Piper 1988). In May 2006, a Cape Griffon was fitted with a GPS unit and a cell phone transmitter, by the Griffon Unit at the De Wildt Cheetah and Wildlife Centre in Gauteng Province. The bird was released at Moholoholo Wildlife Rehabilitation
Centre, in the Lowveld near Hoedspruit in Limpopo Province, and during late November 2006 it travelled over $1000 \mathrm{~km}$ to the Eastern Cape where it stayed in the Winterberg area until late January 2007. The exact position of the bird could be determined whenever it was within range of a cell phone tower. After spending almost two months (7 December 2006 to 31 January 2007) in the Eastern Cape, it followed the same route back to Limpopo Province. During its stay, the bird foraged within a roughly circular area between the towns of Somerset East, Bedford, Adelaide, Tarkastad and Cradock, i.e. the broader Winterberg area. A distance of approximately $74 \mathrm{~km}$ was measured between the two furthest griffon location points, which gives this roughly circular area a radius of about $37 \mathrm{~km}$.

Furthermore, a study of the scavenging behaviour of griffons in southern Africa revealed that at $40 \mathrm{~km}$ from the nearest Cape Griffon colonies the proportion of adults recorded was $91 \%$, at $75-125 \mathrm{~km}$ it was $68 \%$ and at $240-350 \mathrm{~km}$ it was $14 \%$ (Richardson 1984). This decrease in the proportion of adults as the distance from the colony increases was later verified (Piper 1994).

The empirical information provided above indicates that a roughly circular area with a radius of about $40 \mathrm{~km}$ is realistic. This is validated by the results of a study (by Hofmeyr 2000) that created two theoretical (mathematical) foraging models for the Cape Griffon, one of which 
(the flat-disc model) estimated a circular foraging range with a radius of $40 \mathrm{~km}$ in the southern part of the species' range, i.e. the region that includes the Eastern Cape.

Data and information on the location and size of breeding colonies in the study were obtained from Boshoff et al. (2009).

\section{The importance of colony size}

In a declining population, the larger colonies assume a higher conservation importance than the smaller ones (here, colony size is determined by the number of active breeding pairs that are present in any one year). This is underpinned by the notion that for colonially nesting and foraging species, the larger colonies may have, in terms of the costs and benefits of coloniality, a more important ecological and evolutionary role to play than the smaller ones (see discussion in, for example, Danchin \& Wagner 1997 and Brown \& Brown 2001). In this regard, we briefly discuss selected concepts in support of this notion.

(a)The Information-Centre Hypothesis of Ward \& Zahavi (1973) holds that colonies act as centres for the transfer of information that enhances the finding and efficient exploitation of a patchy food supply. Although this hypothesis has been criticised in the literature (see Danchin \& Wagner 1997 and Brown \& Brown 2001), it is still considered likely that an exchange of information can occur at a colony, and theoretical studies have indicated that, as a consequence of coloniality, enhanced foraging efficiency, which affects overall fitness balance, can occur (see the discussion in Brown \& Brown 2001). Should this hypothesis hold, it is postulated that the larger the colony the greater the potential for information transfer.

(b)Part of the Recruitment-Centre Hypothesis of Richner \& Heeb (1996), which has support, holds that the benefits derived from group foraging (i.e. away from the colony), rather than from information transfer at the colony, are likely to favour colony-based foraging. Additional support for this view has been provided by Buckley (1997), who tested the assumption that coloniality may be advantageous because it concentrates foragers (away from the colony), thereby enabling birds to find food more effectively through local enhancement mechanisms. Should this hypothesis hold, it is postulated that the larger the colony the greater the potential for successful foraging.

(c) A large number of studies have shown a positive relationship between colony size and reproductive success (Brown \& Brown 2001). This has been particularly strongly supported by data from studies of colonial seabirds (e.g. Robertson 1986; Barbosa et al. 1997; Lewis et al. 2009). Moreover, in the example of the African penguin Spheniscus demersus, the ability of large colonies to survive, while small ones become extinct, has been shown (Crawford et al. 2001). In an 
example from the Falconiformes, a study of the Lesser Kestrel Falco naumanni revealed that both adult survival and dispersal probability was higher in large colonies, than in medium or small ones (Serrano et al. 2005). However, a possible consequence of coloniality is competition for food amongst colony members, leading to the possible depletion of local food resources (Brown \& Brown 2001). This has been shown for the Eurasian Griffon Gyps fulvus, where breeding success/ productivity was positively correlated with colony size until a point was reached where density-dependent regulation of breeding success occurred, owing to resource limitation in the foraging areas (Fernandez et al. 1998). We have assumed, though, that since the Cape Griffon is in a state of decline throughout its global range, all breeding colonies are likely to be below optimal size, i.e. at a size below that at which density-dependence may function as a limiting factor.

(d)Large griffon colonies are less vulnerable than small ones to stochastic unnatural mortality events at the colony (e.g. caused by disturbance, fire) and away from the colony (e.g. caused by mass poisoning, drowning or electrocution events).

(e)Source-sink theory (Pulliam 1988) holds that a local demographic surplus arises (when births exceed deaths) in good quality habitats, and a local demographic deficit arises (when deaths exceed births) in poor quality habitats, and that individuals from the former (the source) supply the latter (the sink). In the case of the griffons, the larger colonies can be seen as representing the sources and the medium and smaller ones the sinks. Here, the small and medium-sized colonies are likely to yield demographic deficits owing to the combined impact of a range of factors, notably stochastic natural (e.g. fire) and unnatural (e.g. mass poisoning) mortality events, low adult survival rates and high emigration rates, and these sinks are therefore prone to extinction in the absence of immigration and "rescue effects" (Pulliam 1988; Serrano et al. 2005). In the Eastern Cape, it has been postulated that the large colonies are long-standing "nuclear" sites, which persist when the population is in a "waning" (reduction) phase, and that they act as the sources of griffons when the population is in a "waxing" (expansion) phase (Boshoff \& Vernon 1980).

Given the justification provided in (a) to (e) above, and adopting the general principle that for a colonial species such as the Cape Griffon the advantages of a larger colony size are likely to outweigh (albeit to a point) those (if any) of a smaller colony size, we contend that, at this time and for the Cape Griffon in the study area, conservation action focused on breeding colonies (and their associated daily foraging ranges) should start with the larger ones and progress to the smaller ones. 


\section{Results}

Shape and size of daily foraging area

In applying the daily foraging range estimate, we extracted the locations of all the known currently (2000s) active breeding colonies $(n=20)$ of the Cape Griffon in the Eastern Cape from Boshoff et al. (2009) (Table 1) and depicted them as the centres of circular foraging ranges, each with a radius of $40 \mathrm{~km}$ (Figure 1).
However, one colony near the coast ("1" in Figure 1) has the sea within its $40 \mathrm{~km}$ radius but whether, or how, this affects the size and shape of the foraging range associated with this colony is not known. Interestingly, in the case of the Potberg colony (referred to above), which is also near the coast, the griffons maintain a roughly circular foraging range.

Table 1 Maximum number of active nest sites recorded at Cape Griffon breeding colonies in the Eastern Cape Province, South Africa, during the period 2004-2007. Colonies are ranked according to the need for conservation action: $1=$ highest priority; 16 = lowest priority. Data from Boshoff et al. (2009).

\begin{tabular}{|c|c|c|c|c|c|c|}
\hline \multirow{2}{*}{$\begin{array}{l}\text { Priority } \\
\text { ranking }\end{array}$} & \multirow{2}{*}{ Colony } & \multicolumn{2}{|c|}{ Latitude } & \multicolumn{2}{|c|}{ Longitude } & \multirow{2}{*}{$\begin{array}{l}\text { No. of active } \\
\text { nest sites }\end{array}$} \\
\hline & & Deg & Min & Deg & Min & \\
\hline 1 & Msikaba & 31 & 18 & 29 & 55 & 188 \\
\hline 2 & Colleywobbles & 32 & 0 & 28 & 37 & 79 \\
\hline 3 & Ngozi & 31 & 13 & 29 & 16 & 72 \\
\hline 4 & The Castle B & 31 & 6 & 27 & 55 & 47 \\
\hline 5 & Tembukazi & 31 & 21 & 29 & 14 & 43 \\
\hline 6 & Jozana's Hoek & 30 & 40 & 27 & 26 & 40 \\
\hline 6 & Dalhousie & 31 & 13 & 27 & 48 & 40 \\
\hline 7 & Vumenjani & 32 & 23 & 27 & 52 & 25 \\
\hline 7 & Ntsizwa & 30 & 47 & 29 & 16 & 17 \\
\hline 7 & Karnmelkspruit & 30 & 50 & 27 & 14 & 12 \\
\hline 7 & Mbenge & 31 & 35 & 27 & 42 & 11 \\
\hline 7 & Castle Rocks & 30 & 44 & 28 & 25 & 10 \\
\hline 12 & Ndakeni & 30 & 45 & 29 & 10 & 8 \\
\hline 12 & Maxalanga Peak & 31 & 46 & 27 & 10 & 8 \\
\hline 13 & Ntlonze & 31 & 55 & 27 & 27 & 7 \\
\hline 14 & Magusheni & 30 & 52 & 29 & 33 & 6 \\
\hline 15 & Liwalimdaka & 31 & 53 & 27 & 5 & 5 \\
\hline 15 & Dudumashe/Ntabatsolo & 31 & 53 & 27 & 22 & 5 \\
\hline 15 & Kugqebenya & 31 & 47 & 26 & 58 & 5 \\
\hline 16 & Mavis Bank & 30 & 40 & 28 & 1 & 1 \\
\hline
\end{tabular}




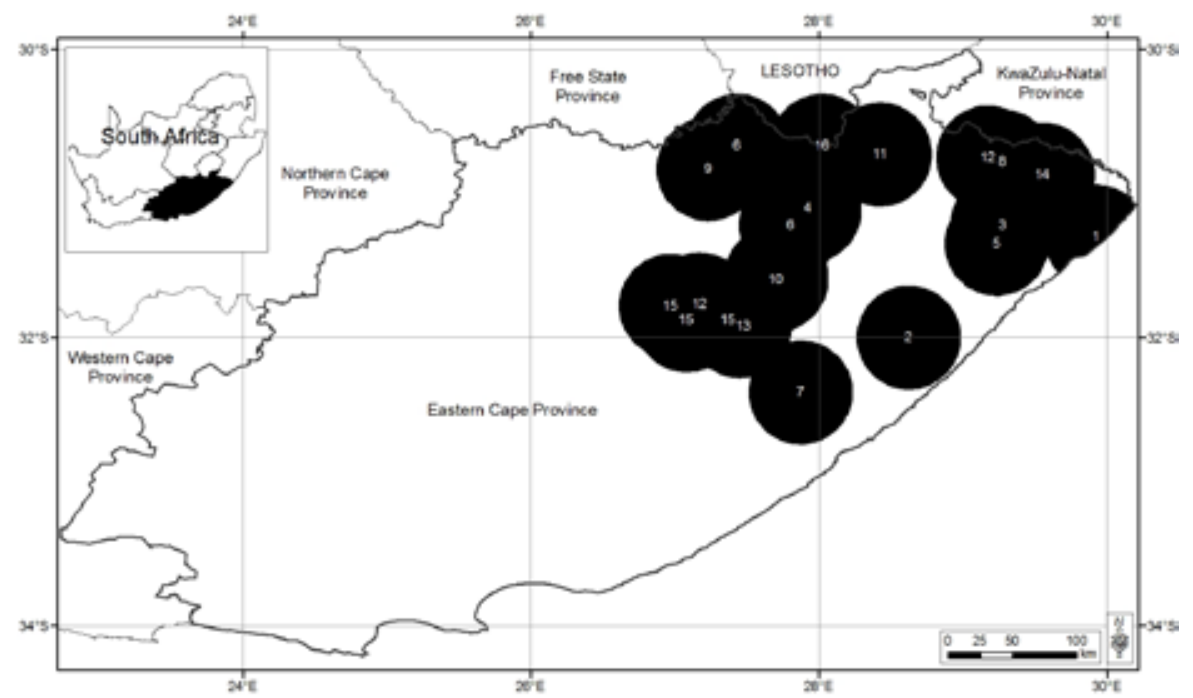

Figure 1. Black circles $($ radii $=40 \mathrm{~km})$ represent estimated daily foraging areas for 20 Cape Griffon breeding colonies in the Eastern Cape Province, South Africa. Numerals at circle centres indicate relative colony size, based on number of active breeding pairs ( $1=$ highest number; $16=$ lowest number). Based on data in Boshoff et al. (2009).

It follows that on-the-ground conservation action to conserve breeding Cape Griffons in the Eastern Cape must be focused in the areas identified as daily foraging ranges (Figure 1). The estimated daily foraging distance from a colony has been used successfully to estimate primary foraging areas for griffons, for example that of a congener - the Eurasian Griffon Gyps fulvus (Fernandez et al. 1998; Xirouchakis \& Andreou 2009).

\section{The importance of colony size}

Following on the arguments presented above, the 20 active breeding sites mentioned in Boshoff et al. (2009) are ranked from 1 (highest number of active nests) to 16 (lowest number of active nests; some sites share the same ranking) (Table 1, Figure 1).

Based on the number of active breeding pairs at each breeding colony (from Boshoff et al. 2009), the cumulative proportion of breeding pairs for combinations of colonies was calculated. This reveals that $30 \%$ (n $=188$ ) of the total breeding pairs in the study area $(\mathrm{n}=629)$ are at one colony (of 20), (i.e. colony 1 on Figure 1), 54\% $(\mathrm{n}=339)$ are at just three colonies (i.e. colonies $1-3)$, and $86 \%(\mathrm{n}=534)$ are at eight colonies (i.e. colonies 1-8) (Table 1, Figure 1). Thus, $85 \%$ of the breeding 
pairs in the province are located at just $40 \%$ of the colonies. Consequently, to achieve maximum impact, conservation action should focus, at least initially, on colonies 1-8, with particular emphasis on colonies 1-3. It is noteworthy that some of the circular daily foraging areas overlap and this will have benefits in a conservation plan. For example, conservation action focused in the foraging range of colonies 3 and 4 will extend over much of the foraging ranges of colonies 5 and 6 , respectively (see Figure 1).

\section{Discussion}

Shape and size of daily foraging area

While the approach to estimate the shape and size of the daily foraging range is readily applicable to the remainder of the species' global range, the size and shape of the daily foraging area may need to be adjusted, according to the nature of the foraging habitat. For example, using a mathematical modelling\# approach, it was predicted that in the northern part of the global range of the Cape Griffon, the radius of a roughly circular foraging area could be around $85 \mathrm{~km}$ (Hofmeyr 2000). This is supported by the comparatively large foraging ranges recorded for marked Cape Griffons in a study in Namibia (Bamford et al. 2007).

\section{The importance of colony size}

Against the backdrop of an unbounded sub-regionally occurring species such as the Cape Griffon, a shortcoming of our study is that it ignores the presence and size of griffon colonies across the borders of the Eastern Cape, i.e. in the grasslands of neighbouring Lesotho and in southern Free State and western KwaZulu-Natal provinces. Undoubtedly, had the data and information from those colonies been available, and included in our analysis, the listing of the colonies according to size (Table 1, Figure 1) would have been somewhat different.

Currently the contemporary Cape Griffon data required to attempt a global scale analysis either do not exist, or are not available in the open literature, and, given the declining capacity of national conservation NGOs and most government conservation entities in southern Africa, it appears unlikely that this situation will be reversed any time soon.

We therefore contend that conservation action in any one political region (country or province) should not be held back because of a lack of data and information in others. In this regard, the information in this note provides a sound starting point for the conservation of the Cape Griffon population in the Eastern Cape. If and when new information becomes available from adjacent regions, then this plan can be modified accordingly. This view is supported by the reality that within the range of the Cape Griffon in southern Africa, conservation agencies are highly regionalised, with each country or province having its own conservation authority. In South Africa, alone, there 
are nine provinces, each with its own conservation agency. If the conservation authority in the Eastern Cape has the commitment and resources to proceed with a griffon conservation programme it can do so, without having to wait for others to reach the same position.

\section{General}

The information contained in Table 1 and Figure 1 is considered to be useful for guiding the development, resourcing and implementation of a first phase of a conservation plan for the Cape Griffon in the Eastern Cape, namely to protect the breeding segment of the population. For example, it can be used to prioritise areas where mitigation of griffon-unfriendly powerline infrastructure is required, and areas where only griffon-friendly infrastructure should be used on new powerlines. Similarly, it can be used to prioritise areas for conducting focused awareness campaigns to encourage stock farmers to (a) leave chemically uncontaminated stock carcasses on the land, (b) use alternative predator control methods to poison, (c) report cases of illegal harvesting of griffons for the animal trade industry, (d) mitigate high-walled cement reservoirs to prevent griffon drownings, and (e) report the presence of dead griffons, to allow the causes of deaths to be investigated, and mortality rates to be estimated.

The logical second phase of the conservation plan involves the identification of priority areas to protect the non-breeding segment of the population, which occupies a slightly more expanded area than does the breeding segment (Minnie 2009).

\section{Acknowledgements}

We thank the De Wildt Cheetah and Wildlife Trust for permission to use distributional data from a cell-phone and GPS equipped griffon. Two reviewers are thanked for their suggestions on an earlier version of the article.

\section{Key words:}

Cape Griffon, South Africa, foraging areas, breeding colonies, conservation planning, site prioritisation

\section{References}

Anderson, M.D. 2000. Cape vulture. In: Barnes, K.N. (ed.). The Eskom Red Data Book of Birds of South Africa, Lesotho and Swaziland. BirdLife South Africa, Johannesburg. pp 73-75.

Bamford, A.J., Diekmann, M., Monadjem, A. \& Mendelsohn, J. 2007. Ranging behaviour of Cape Vultures Gyps coprotheres from an endangered population in Namibia. Bird Conservation International 17: 331-339. 
Barbosa, A., Moreno, J., Potti, J. \& Merino, S. 1997. Breeding group size, nest position and breeding success in the chinstrap penguin. Polar Biology 18: 410-414.

Bell, B.D. \& Merton, D.V. 2002. Critically endangered bird populations and their management. In: Norris, K. \& Pain, D.J. (eds). Conserving bird diversity. General principles and their application. Cambridge University Press, Cambridge. pp. 105-138.

Boshoff, A.F. \& Vernon, C.J. 1980. The past and present distribution and status of the Cape Vulture in the Cape Province. Ostrich 51: 230-250.

Boshoff, A.F., Piper, S.E. \& Michael, M.D. 2009. On the distribution and breeding status of the Cape Griffon Gyps coprotheres in the Eastern Cape Province, South Africa. Ostrich 80: 85-92.

Brown, C.R. \& Brown, M.B. 2001. Avian coloniality: progress and problems. Current Ornithology 16: 1-82.

Brown, C.J., \& Piper, S.E. 1988. Status of Cape Griffons in the Natal Drakensberg and their cliff site selection. Ostrich 59: 126-136.

Buckley, N.J. 1997. Spatial-concentration effects and importance of local enhancement in the evolution of colonial breeding in seabirds. American Naturalist 149: 1091-1112.

Carrete, M. \& Donazar, J.A. 2005. Application of central-place foraging theory shows the importance of Mediterranean Dehesas for the conservation of the Cinereous Griffon, Aegypius monachus. Biological Conservation 126: 585-590.

Crawford, R.J.M., David, J.H.M., Shannon, L.J., Kemper, J., Klages, N.T.W., Roux, J-P., Underhill, L.G., Ward, V.L., Williams, A.J. \& Wolfaardt, A.C. 2001. African penguins as predators and prey - coping (or not) with change. South African Journal of Marine Science 23: 435-447.

Danchin, E. \& Wagner, R.H. 1997. The evolution of coloniality: the emergence of new perspectives. Trends in Ecology and Evolution 12: 342-347.

Deygout, C., Gault, A., Sarrazin, F. \& Bessa-Gomes, C. 2009. Modeling the impact of feeding stations on vulture scavenging service efficiency. Ecological Modelling 220: 1826-1835.

Fernandez, C., Azkona, P. \& Donazar, J.A. 1998. Density-dependent effects on productivity in the Griffon Vulture Gyps fulvus: the role of interference and habitat heterogeneity. Ibis 140: 64-69.

Hofmeyr, S.D. 2000. Theoretical foraging models for the Cape Griffon Gyps coprotheres. Hons dissertation. University of Natal, Pietermaritzburg.

IUCN. 2009. 2009 IUCN Red List of Threatened Species. www.iucnredlist.org Jarvis, M.J.F., Siegfried W.R. \& Currie, M.H. 1974. Conservation of the Cape Griffon in the Cape Province. Journal of the Southern African Wildlife Management Association 4: 29-34. 
Lewis, S., Elston, D.A., Daunt, F., Cheney, B. \& Thompson, P.M. 2009. Effects of extrinsic and intrinsic factors on breeding success in a long lived seabird. Oikos 118: 521-528.

Minnie, J. 2009. Habitat and foraging models as aids in the identification of priority areas for mitigating actions to reduce the incidence of electrocutions of the threatened Cape Griffon Gyps coprotheres in the Eastern Cape. M.Sc. dissertation. Nelson Mandela Metropolitan University. Port Elizabeth.

Mucina, L. \& Rutherford, M.C. (eds). 2006. The Vegetation of South Africa, Lesotho and Swaziland. Strelitzia 19. South African National Biodiversity Institute, Pretoria.

Mundy, P.J. 1982. The comparative biology of southern African vultures. Vulture Study Group, Johannesburg.

Mundy, P.J., Benson, P.C. \& Allan, D.G. 1997. Cape vulture. In: Harrison, J.A., Allan, D.G., Underhill, L.G., Herremans, M., Tree, A.J., Parker, V. \& Brown, C.J. (eds) The Atlas of southern African Birds. Vol. 1. BirdLife South Africa, Johannesburg. pp 158-159.

Mundy, P.J., Ledger, J.A., Friedman, R. \& Piper, S.E. 1992. The Vultures of Africa. Acorn Books \& Russell Friedman Books, Randburg.

Newton, I. 1979. Population ecology of raptors. T. \& A.D. Poyser, Berkhamsted.

Orians, G.H. \& Pearson, N.E. 1979. On the theory of central place foraging. In: Horn, D.J., Mitchel, R.D. and Stairs, G.R. (eds). Analysis of Ecological Systems. Ohio State University Press, Columbus. pp 154-177.

Piper, S.E. 1994. Mathematical demography of the Cape Griffon. Ph.D. thesis, University of Cape Town.

Piper, S.E. 2005. Cape Vulture. In: Hockey, P.A.R., Dean, W.R.J. \& Ryan, P.G. (eds). Roberts - Birds of southern Africa. VII ${ }^{\text {th }}$ ed. John Voelcker Bird Book Fund, Cape Town. pp 489-491.

Pulliam, H.R. 1988. Sources, sinks and population regulation. American Naturalist 132: 652-661

Richardson, P.R.K. 1984. The scavenging behaviour of griffons in southern Africa. Proceedings of the Fifth Pan-African Ornithological Congress pp. 331-353.

Richner, H. \& Heeb, P. 1996. Communal life: honest signalling and the recruitment center hypothesis. Behavioural Ecology 7: 115-118.

Robertson, G. 1986. Population-size and breeding success of the gentoo penguin, Pygoscelis-Papua, at Macquarie Island. Australian Wildlife Research 13: 583-587.

Robertson, A.S. \& Boshoff, A.F. 1986. The feeding ecology of Cape Vultures Gyps coprotheres in a stock-farming area. Biological Conservations 35: 63-86.

Serrano, D., Oro, D., Esperanza, U. \& Tella, J.L. 2005. Colony size determines adult survival and dispersal preferences: allee effects in a colonial bird. American Naturalist 166: E22-E31 
Vernon, C.J. \& Boshoff, A.F. 1997. A review of the status of vultures in the Eastern Cape Province, South Africa. In: Boshoff, A.F., Anderson, M.D. \& Borello, W.D. (eds). 1997. Vultures in the 21st Century: Proc. of a Workshop on Vulture Research and Conservation in southern Africa. Vulture Study Group, Johannesburg. pp. 50-56.

Ward, P. \& Zahavi, A. 1973. The importance of certain assemblages of birds as 'information centres' for food finding. Ibis 115: 517-534.

Xirouchakis, S.M. \& Andreou, G. 2009. Foraging behaviour and flight characteristics of Eurasian griffons Gyps fulvus in the island of Crete, Greece. Wildlife Biology 15: 37-52.

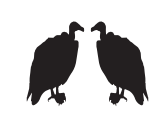

